\title{
КОНЦЕПТУАЛЬНІ ПІДХОДИ ДО ПРОЕКТУВАННЯ ОСВІТНЬОГО ІНФОРМАЦЙНО-КОМУНІКАЦІЙНОГО СЕРЕДОВИЩА
}

Лопушинський I. П., д-р наук з держ., упр., профессор, Херсонський національний технічний університет, м. Херсон, Україна

Дурман О. Л., ст. викладач, Херсонський національний технічний університет, м. Херсон, Україна

У статті розглядаються підходи до вдосконалення організаційного механізму управління освітньою галуззю.

Визначено, щзо на сьогодні існує некомфортний стан управління через недостатню кількість інформаџії про діяльність ЗВО або про значний час, потрібний для ї̈ отримання. Для ліквідації такого стану пропонується застосовувати підходи, засоби та інструменти, щзо їх пропонують сучасні інформачійно-комунікаційні технології. Так, для оптимізації процесів ухвалення управлінських рішень пропонується застосовувати підходи теорії ухвалення рішень та проектування і створення відповідних інформаційних систем. Зв'язки розподіляються на суб 'єктно-об 'єктні (прямі), об 'єктно-суб 'єктні (зворотні), а також суб'єктно-суб'єктно та об'єктні-об'єктні. Зважаючи на те, щзо успіх управлінської діяльності певною мірою залежить від дотримання системного принципу зворотного зв'язку інформаційних потоків, його сутність полягає у зв'язку між отриманим ефектом та управлінським впливом.

Для підвищення якості та швидкості ухвалення управлінських рімень в освітній галузі пропонується формування єдиного освітнього інформачійно-комунікаційного середовища, а також використання інформаційних технологій в освітній галузі. Автором зроблено висновки, що подальші розробки можуть бути спрямовані 
на вивчення та вдосконалення механізмів державного управління освітньою галуззю через децентралізацію та дерегулячію державного управління з метою підвищення його ефективності.

Це дасть змогу поліпшити взаємодію різних рівнів управління освітньою галуззю як по вертикалі, так і по горизонталі. Крім того, пропонується також поширити ичей підхід $і$ на інші сфери державного управління.

Ключові слова: державне управління; освітня галузь; система вищої освіти; заклад вищої освіти; системи підтримки ухвалення рімень; освітне інформаційно-комунікачійне середовище.

Постановка проблеми у загальному вигляді. До системи державного управління належать різні сфери життєдіяльності (економічна, аграрна, юридична тощо), кожна сфера має свої недоліки в механізмах управління складових, особливо ж це відчувається у відсутності прозорості управління. У кожній сфері (галузі) діють механізми державного управління (організаційні, правові, фінансові тощо), пристосовані до такої сфери. Таким чином, через відповідні механізми державного управління держава проводить свою політику управління у відповідних сферах.

Водночас останнім часом виникла потреба змінити не лише підходи до формування принципів такої політики управління, але й підходи до формування інноваційної платформи ефективної комунікації в інформаційному просторі. Саме тому державне управління як складна соціальна система, так і її складові (сфери, галузі діяльності), потребують змін і вдосконалення. Для того, щоб керівники вищих рівнів ухвалювали виважене та своєчасне управлінське рішення, управлінський діалог повинен будуватися як за вертикальною схемою, так і за горизонтальною - із застосуванням сучасних інформаційних технологій у єдиному інформаційно-комунікаційному середовищі. Стосується це й освітньої галузі, головним органом державної влади в якій є Міністерство освіти і науки України (далі $\mathrm{MOH} \mathrm{України).} \mathrm{Як} \mathrm{орган} \mathrm{державної} \mathrm{влади} \mathrm{МОН} \mathrm{України} \mathrm{виконує}$ й інші функції, наприклад, координує діяльність різних державних агенцій та служб, тому його вплив на суспільство не обмежується 
тільки сферою освіти, але й стосується інших напрямків державного управління.

У нашому дослідженні пропонується розглянути, як приклад, удосконалення механізмів державного управління саме в освітній галузі.

Аналіз останніх досліджень та публікацій. Сьогодні можна зустріти значну різноманітність визначень поняття «механізми державного управління». Цей термін у своїх працях розкривають такі науковці, як: В. Авер'янов, Г. Атаманчук, В. Бакуменко та В. Князєв, Н. Нижник та О. Машков, Р. Рудніцька, В. Малиновський, О. Оболенський, М. Корецький та ін.

Методологічні основи процесів управління в соціальних системах, до яких належать і процеси державного управління, розглядає у своїх роботах В. Бакуменко [1]. Системний підхід та використання сучасних інформаційних технологій для підтримки ухвалення рішень висвітлюється в роботах О. Половцева [2]. Проблемам дерегуляції процесів державного управління присвячені роботи М. Дурмана [3]. Проблемам формування та реалізації державної політики в галузі освіти, теорії і практики державного управління освітою, удосконалення механізмів державного управління в галузі освіти присвячені роботи Д. Дзвінчука [4], С. Домбровської [5], І. Лопушинського [6], Т. Лукіної [7], Р. Науменко [8], Л. Паращенко [9], Н. Протасова [10] та ін.

Проте питання вдосконалення організаційного механізму державного управління освітньою галуззю засобами єдиного інформаційно-комунікаційного середовища на сьогодні в науковій літературі майже не висвітлено. Крім того, недостатньо уваги в літературі надається питанням дерегулювання процесів та процедур, що складають той фундамент, на якому функціонує вся освітня галузь - ліцензування, акредитація, оцінка якості освіти, принципи розподілу коштів на освіту і науку тощо. Усе це призводить до виникнення некомфортного стану в державному управлінні, через який неможливо досягнути високого рівня якості управлінських рішень.

Формулювання цілей статті (постановка завдання). Саме тому метою нашої статті постало завдання проаналізувати наявну на сьогодні модель інформаційно-комунікаційного забезпечення 
управління освітою та запропонувати нові підходи до проектування і формування єдиного інформаційно-комунікаційного середовища 3 метою забезпечення ефективної комунікації в інформаційному просторі освітньої галузі.

Виклад основного матеріалу дослідження. Україна є соціальною державою, оскільки одним із основних їі обов'язків є забезпечення та захист прав і свобод людини, підвищення рівня життя громадян, формування в суспільстві таких моделей поведінки, які повинні базуватися на повазі до закону та дотриманні моральних настанов. Відповідно до Конституції України, держава зобов'язана надати своїм громадянам послуги у сфері охорони здоров'я, освіти, житлово-комунального господарства, охорони громадського порядку, соціального забезпечення тощо. Виходячи з такої постановки питання, важливої ваги набуває запровадження новітніх моделей забезпечення якості системи державного управління.

Розглядаючи систему державного управління як одну 3 підсистем соціальної системи, доцільно зазначити, що будь-яка підсистема, у свою чергу, теж поділяється на складові. Прикладом такої розгалуженості може виступати Кабінет Міністрів України, до складу якого входять різногалузеві профільні міністерства (центральні органи виконавчої влади), яким підпорядковуються підрозділи та організації по всій країні (територіальні підрозділи центральних органів виконавчої влади).

Модернізація всієї вертикалі публічного управління неможлива без необхідних знань та освіти. Освіта - важлива сфера людської життєдіяльності, стратегічний чинник соціально-економічного, інтелектуального та духовного розвитку суспільства. За визначенням, прийнятим ХХ сесією Генеральної конференції ЮНЕСКО, під освітою розуміється процес і результат удосконалення здібностей i поведінки особистості, за якого вона досягає соціальної зрілості та індивідуального зростання. Освіта являє собою соціальний процес відтворення і нагромадження інтелектуального та культурного потенціалу [11].

Освіта - багатофункціональна галузь. Ї̈̈ важливими функціями $\epsilon$ пізнавальна, виховна, розвивальна, координувальна, адаптаційна, 
профорієнтаційна, економічна, соціального захисту тощо. Вона одночасно постає як єдність п'яти якостей: як цінність, як процес, як результат, як послуга і як система [12].

Об'єктивно освіта належить до вищих цінностей людини і суспільства - вона $є$ передумовою їх існування та розвитку. Саме у сфері освіти послідовно розвиваються здібності та формуються життєві прагнення всього населення. Чим вищий освітній рівень особистості, тим ширші її можливості для створення оптимальних умов життя і праці. Освічена особистість - це не лише ії власне надбання, але й надбання суспільства в цілому.

Як відомо, освітню галузь України як підсистему державного управління очолює Міністерство освіти і науки України (МОН України), до складу якого входять департаменти різних напрямів, які керують дошкільною та загальною середньою, вищою освітою, науковою, міжнародною діяльністю тощо. Крім того, МОН України керує діяльністю відповідних департаментів, що входять до нього. Оскільки нас цікавить гілка вищої освіти, тому вертикальна структура, яку ми досліджуємо, почнеться із МОН України і закінчиться закладом вищої освіти, його структурними підрозділами (відділами і кафедрами).

Згідно з постановою Кабінету Міністрів України від 16 жовтня 2014 р. № 630 «Про затвердження положення про Міністерство освіти і науки України» (далі - Положення), МОН України є центральним органом виконавчої влади, діяльність якого спрямовується і координується Кабінетом Міністрів України [13].

МОН України входить до системи органів виконавчої влади і $€$ головним органом у системі центральних органів виконавчої влади із забезпечення формування та реалізації державної політики у сферах освіти і науки, інтелектуальної власності, наукової, науково-технічної та інноваційної діяльності, інформатизації, формування і використання національних електронних інформаційних ресурсів, створення умов для розвитку інформаційного суспільства, а також у сфері здійснення державного нагляду (контролю) за діяльністю навчальних закладів незалежно від їх підпорядкування і форми власності.

МОН України у своїй діяльності керується Конституцією та законами України, актами Президента України, Кабінету Міністрів 
України, іншими актами законодавства, дорученнями Президента України, а також вищеназваним Положенням.

На МОН України, як і на інші міністерства та відомства, покладено багато інших завдань, деякі з них, наприклад [14]:

- розроблення стратегії розвитку та форматів вітчизняної освіти, інших стратегічних документів, відповідних державних цільових програм, участь у їх реалізації та надання методичних рекомендацій, і все це - 3 неухильним збереженням та захистом національних інтересів;

- нормативно-правове забезпечення функціонування системи освіти;

- збирання та оброблення освітньої статистики, їі аналіз і дальші прогнози;

- міжнародне співробітництво у сфері освіти і науки;

- формування пропозицій про обсяг та подекуди розподіл освітніх субвенцій та державного фінансування різних видів освіти і стипендіального фонду;

- визначення державних пріоритетів з підготовки та перепідготовки освітян; їхня сертифікація та підвищення кваліфікації;

- розроблення та затвердження умов прийому до навчальних закладів; умов провадження освітньої діяльності, її ліцензування та перевірка;

- затвердження порядку проведення інституційного аудиту закладів освіти, акредитації типових освітніх програм та інших заходів контролю якості освіти тощо.

МОН України в межах повноважень, на основі та на виконання Конституції та законів України, актів і доручень Президента України, актів Кабінету Міністрів України видає накази, організовує та контролює їх виконання.

Тобто МОН - це структура, яка представлена у вигляді системи. Важливою складовою в управлінні структурою є управлінські відносини, проте це не лише розподіл завдань на підзавдання, а й дальший процес їх виконання, зв'язки і відносини, що виникають при цьому, зокрема для подолання знову виявлених проблем. 
Управлінські відносини в державному управлінні взагалі і в Міністерстві освіти і науки України зокрема, будуються на засадах владної субординації, тобто розуміється як «розпорядження - виконання» в системі суб'єкт управління - об'єкт управління.

Зв'язки розподіляються на суб' єктно-об'єктні (прямі), об'єктносуб'єктні (зворотні), а також суб'єктно-суб'єктно та об'єктніоб'єктні. Зважаючи на те, що успіх управлінської діяльності певною мірою залежить від дотримання системного принципу зворотного зв'язку інформаційних потоків, його сутність полягає у зв'язку між отриманим ефектом та управлінським впливом. Саме тому В. Новак тлумачить зворотний зв'язок як інформаційне забезпечення управлінського процесу, що в соціальному варіанті $є$ необхідною умовою ефективності управлінських рішень [15].

Як уже зазначалося, удосконалення моделі публічного управління ми плануємо почати 3 освітньої галузі, а саме 3 управління вищою освітою. За ситуації, яку ми спостерігаємо в плані об'єктсуб'єктних відносин, можна стверджувати: на рівні відносин «Міністр - ректор» зворотний зв'язок ще діє, а ось на рівні «Міністр викладач» або, навіть «ректор - викладач» механізму забезпечення об'єктивною, достовірною і своєчасною інформацією фактично не існує. Серед основних причин цього становища - відсутність єдиної інформаційно-комунікаційної платформи освітньої галузі, яка б автоматизувала і полегшила зв'язок між МОН України та ЗВО в контексті державного управління.

Водночас певні кроки в цьому напрямку вже здійснюються, проте вони, здебільшого, стосуються власне внутрішньої роботи МОН України. Наприклад, починаючи з травня 2016 року, в межах Проекту USAID «Альянс сприяння прозорому управлінню освітою в Україні - UTEMA» МОН України впроваджується електронний документообіг. Проектом передбачений поетапний перехід до системи електронного управління і документообігу - спочатку в рамках Міністерства, а згодом - в інших установах освітньої сфери [16]. Технічну базу для цього надають Американські ради в межах проекту міжнародної технічної допомоги USAID, а основу для програмного забезпечення - Адміністрація Президента України. Наразі 
відбувається технологічне налаштування такої системи під потреби Міносвіти [17].

Крім того, у червні 2016 року Кабінетом Міністрів України було затверджено Стратегію реформування державного управління України на 2016-2020 роки [18]. Стратегія передбачає вдосконалення державної системи управління згідно з європейськими стандартами, прописаними в програмі SIGMA (Support for Improvement in Governance and Management - Програма підтримки вдосконалення врядування та менеджменту), що є спільною ініціативою ОЕСР та Євросоюзу [19].

У ході співпраці України та Програми SIGMA передбачається також адаптація структур, що формують державні політики у різних галузях (центральні органи виконавчої влади), до європейських стандартів державного управління, у тому числі й через запровадження сучасних інформаційно-комунікаційних технологій та реінжинірингу управлінських процесів у таких структурах.

У результаті проведеного нами аналізу наявних управлінських процесів, у тому числі пов'язаних з інформаційно-комунікаційним забезпеченням державного управління освітньою галуззю, було виявлено певні недоліки. Основним із них можна вважати певну затримку при формуванні та обміні інформаційними потоками між рівнями управління, наприклад Міністр $\leftrightarrow$ ректор $\leftrightarrow$ кафедра (відділ) ↔ викладач (фахівець), що призводить до оперування в управлінській діяльності застарілою, неповною та неточною інформацією, що, своєю чергою, знижує ефективність управління загалом.

Саме тому існує потреба формування ефективної комунікації між керівництвом та структурними підрозділами 3ВО, що дасть змогу створити новий механізм управління інформаційно-комунікативним простором 3ВО через використання адаптованих взаємозалежних технологічних інновацій.

Ефективне функціонування інформаційно-комунікаційного простору залежить від таких умов:

- якісне задоволення потреб фізичних і юридичних осіб у необхідних їм знаннях, уміннях і навичках;

- у управлінська воля МОН щодо поширення цього середовища на всі заклади вищої освіти, які підпорядковуються Міністерству; 
- наявність науково обгрунтованої концепції розвитку інформаційно-комунікаційного простору галузі вищої освіти;

- раціональне використання інтелектуальних, матеріальних, інформаційних і фінансових ресурсів при одночасному досягненні максимальної ефективності управлінської діяльності тощо [20].

Досягнення ж максимальної ефективності будь-якої діяльності $\epsilon$ результатом процесу проектування цієї діяльності та ії здійсненням. Оскільки ж ми вказали вище на недоліки наявних механізмів державного управління освітньою галуззю, то спробуємо вдосконалити організаційний механізм управління освітньою галуззю, запропонувавши спроектувати нову модель взаємодії у галузі вищої освіти через створення єдиного освітнього інформаційно-комунікаційного середовища.

У Законі України «Про Національну програму інформатизації» подається таке визначення проекту інформатизації: «Проект інформатизації - комплекс взаємопов'язаних заходів, як правило, інвестиційного характеру, що узгоджені за часом, використанням певних матеріально-технічних, інформаційних, людських, фінансових та інших ресурсів і мають на меті створення заздалегідь визначених інформаційних і телекомунікаційних систем, засобів інформатизації та інформаційних ресурсів, які відповідають певним технічним умовам і показникам якості» [21].

Одним із ключових понять проектування інформаційних систем $€$ життєвий цикл проекту - Project Life-Cycle Management (PLCM). У загальному він визначається моделлю й описується у формі методології (методу). Модель або парадигма життєвого циклу визначає загальну організацію життєвого циклу (ЖЦ) i, як правило, основні його фази та принципи переходу між ними, оскільки модель ЖЦ - це структура, що складається із процесів, робіт та завдань, які охоплюють розроблення, експлуатацію і супровід програмного продукту. Модель охоплює життя системи від визначення вимог до неї до припинення ії використання. А методологія (метод) визначає комплекс робіт, їх детальний зміст і рольову відповідальність спеціалістів на всіх етапах вибраної моделі ЖЦ. Вона рекомендує практики (best practices), що дозволяють максимально ефективно використовувати відповідну методологію та ії модель [22]. 
Проектування інформаційних систем, як правило, характеризується такими особливостями [23]:

- складність опису (велика кількість функцій, процесів, елементів даних і складні взаємозв'язки між ними), що вимагає ретельного моделювання й аналізу даних і процесів;

- наявність сукупності компонентів (підсистем), що тісно взаємодіють, виконують певні локальні завдання та цілі функціонування (наприклад, додатків, пов'язаних з обробленням трансакцій і розв'язанням регламентних завдань, додатків аналітичного оброблення (підтримки ухвалення рішень), які використовують нерегламентовані запити до даних великого обсягу);

- відсутність прямих аналогів, що обмежує можливість використання типових проектних рішень і прикладних систем;

- потреба узгодження наявних додатків з новими розробками;

- функціонування в неоднорідному середовищі на кількох апаратних платформах;

- різнорідність рівня кваліфікації та сформованих традицій використання певних наборів інструментальних засобів у групах розробників;

- істотна тривалість проекту, зумовлена, з одного боку, обмеженими можливостями колективу розробників; з іншого боку, масштабами організації-замовника і різним ступенем готовності окремих іiі підрозділів до впровадження IC.

Для успішної реалізації проекту об'єкт проектування, а в нашому випадку - це єдиний освітній інформаційно-комунікаційний простір, повинен бути насамперед адекватно описаний, побудовані повні й несуперечливі функціональні та інформаційні моделі [24; 25].

Особливо вагомим у вертикалі освітньої галузі $\mathrm{MOH} \leftrightarrow 3 \mathrm{BO} \leftrightarrow$ кафедри ↔ викладачі при впровадженні єдиного освітнього інформаційно-комунікаційного середовища залишається питання формування механізмів ухвалення управлінських рішень за рахунок розвитку інформаційних систем підтримки ухвалення рішень (СПУР).

Стосовно цього, О. Половцев довів, що найбільш актуальним напрямом дослідження процедур ухвалення рішень $є$ формалізація цих процесів та розвиток систем підтримки ухвалення рішень за ра- 
хунок посилення низових та середніх ланок державного управління. Такий напрям зумовлено зростанням потреби обліку та врахування значної кількості пов'язаних між собою чинників, що швидко змінюються; зростанням потреб зняття невизначеності у низових ланках, які пов'язані з неможливістю вимірювання окремих чинників впливу; зростанням вагомості наслідків управлінських рішень. Названим дослідником розглядалися проблеми формування оптимальної моделі ухвалення управлінських рішень у сфері державного управління 3 урахуванням обмеженості ресурсів. Ним доведено, що основним інструментом у визначених моделях $є$ процедура експертного оцінювання, у якій головним елементом $є$ процес коректного отримання інформації. Учений наголошує, що для оцінювання об'єктів у слабкоструктурованих завданнях слід застосовувати апарат теорії нечітких множин, зокрема у випадках розподілу ресурсів [2].

Як відомо, у процесі ухвалення управлінських рішень доводиться враховувати значну кількість показників, критеріїв, чинників, що впливають на освітню діяльність. Щодня доводиться стикатися 3 різного роду невизначеностями, пов'язаними з суперечливістю критеріїв, неповнотою інформації про проблему, неможливістю кількісного виміру тих чи інших чинників і показників. Водночас керівник повинен бачити невідповідності внутрішнього середовища закладу вимогам зовнішнього середовища, вміти аналізувати різні варіанти розвитку освітньої діяльності, бачити перспективу.

За своїм змістом узгодженість завжди передбачає встановлення і підтримання об'єктивно необхідних кількісних і якісних взаємозв'язків між різними частинами системи, послідовність їх здійснення в часі і просторі, певний розподіл наявних ресурсів в інтересах найбільш успішного досягнення цілей управління. У будьякій системі найважливіше значення має встановлення узгодженості (взаємозв'язку) між цілями управління і засобами їх досягнення.

3 метою створення СПУР для можливості використання в освітніх закладах нами було вивчено принципи побудови інформаційного середовища. Структурна схема роботи 3 даними дає можливість бачити, як відбувається обмін інформацією і ухвалення рішення в управлінському ланцюжку СПУР (рис. 1). 


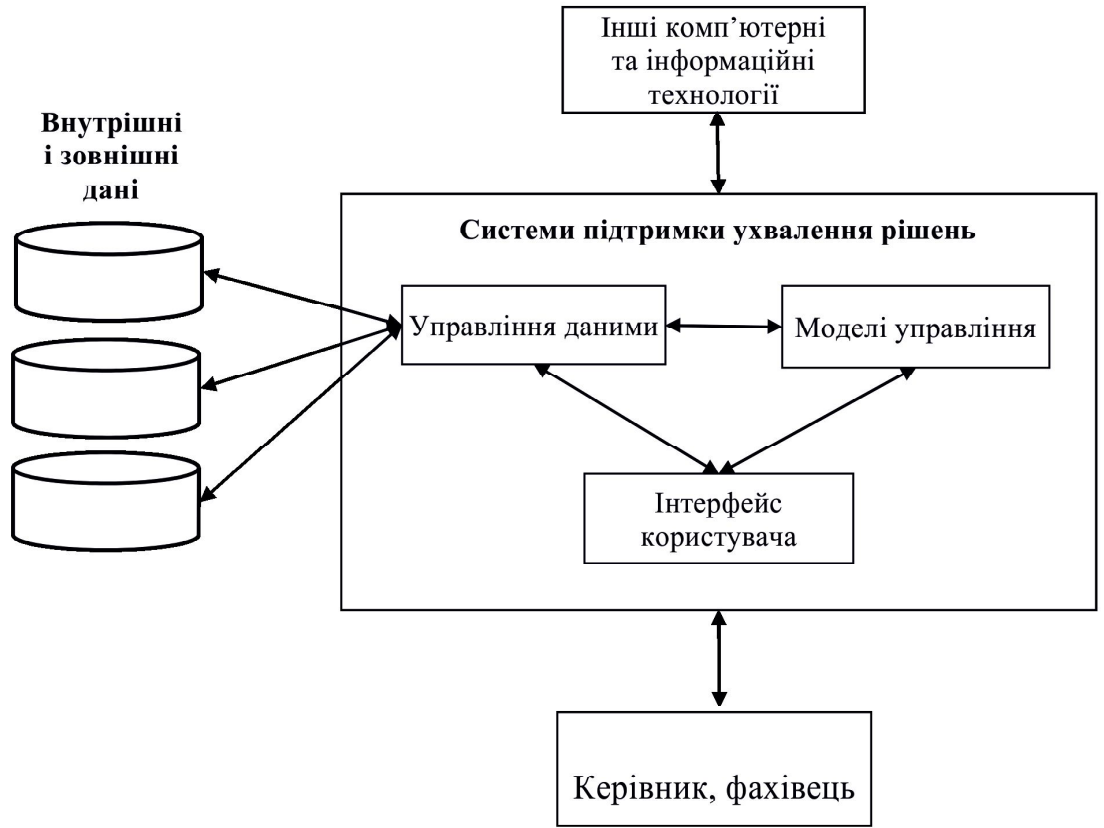

Рис. 1. Структурна схема роботи з даними у СППР

*Джерело: взяте з Інтернету

Таким чином, необхідна єдина концепція побудови інформаційно-комунікаційного середовища, що повною мірою враховує нові можливості створення, поширення й застосування багатокомпонентних розподілених і інтегрованих баз даних, орієнтованих на процес управління і звітування.

Далі розглянемо управління освітньою галуззю як систему, що поєднує за допомогою мережевих технологій, програмні та технічні засоби та організаційне забезпечення, призначене для підвищення ефективності управління і доступності інформації.

Аналіз переваг і недоліків, що існують в інформаційно-комунікаційному середовищі вищої освіти, дозволяє сформулювати такі принципи, на яких повинні будуватися проектовані нині структури: 
- багатокомпонентність - інформаційно-комунікаційне середовище являє собою багатокомпонентне середовище, що включає навчально-методичні матеріали, наукомістке програмне забезпечення, тренінгові системи, системи контролю, технічні засоби, бази даних й інформаційно-довідкові системи, сховища інформації будь-якого виду, включаючи графічні, відео та ін., взаємозалежні між собою у своїй діяльності;

- інтегральність - інформаційний компонент інформаційнокомунікаційного середовища повинен містити в собі всю необхідну сукупність базових знань у галузі вищої освіти з виходом на всі 3ВО, що підпорядковані МОН країни, а надалі і на всю систему державного управління з різними галузями життєдіяльності;

- розподіленість - інформаційний компонент інформаційнокомунікаційного середовища повинен бути оптимальним образом розподіленим по сховищах інформації (серверам) з урахуванням вимог і обмежень сучасних технічних засобів і економічної ефективності;

- адаптивність - інформаційно-комунікаційне середовища не повинно відторгатися чинною системою вищої освіти, порушувати структури та принципи побудови, а повинне дозволити гнучко модифікувати інформаційне ядро системи, адекватно віддзеркалюючи потреби суспільства.

Сформульовані принципи побудови інформаційно-комунікаційного середовища роблять необхідним розгляд інформаційно-комунікаційного середовища, з одного боку, як частину традиційної систем вищої освіти, а з іншого - як самостійну систему, спрямовану на вдосконалення механізмів управлінської діяльності в системі державного управління взагалі і в системі вищої освіти зокрема із застосуванням інформаційних технологій.

Структуру освітнього інформаційно-комунікаційного середовища, що пропонується в нашому дослідженні, подано на рис. 2. 


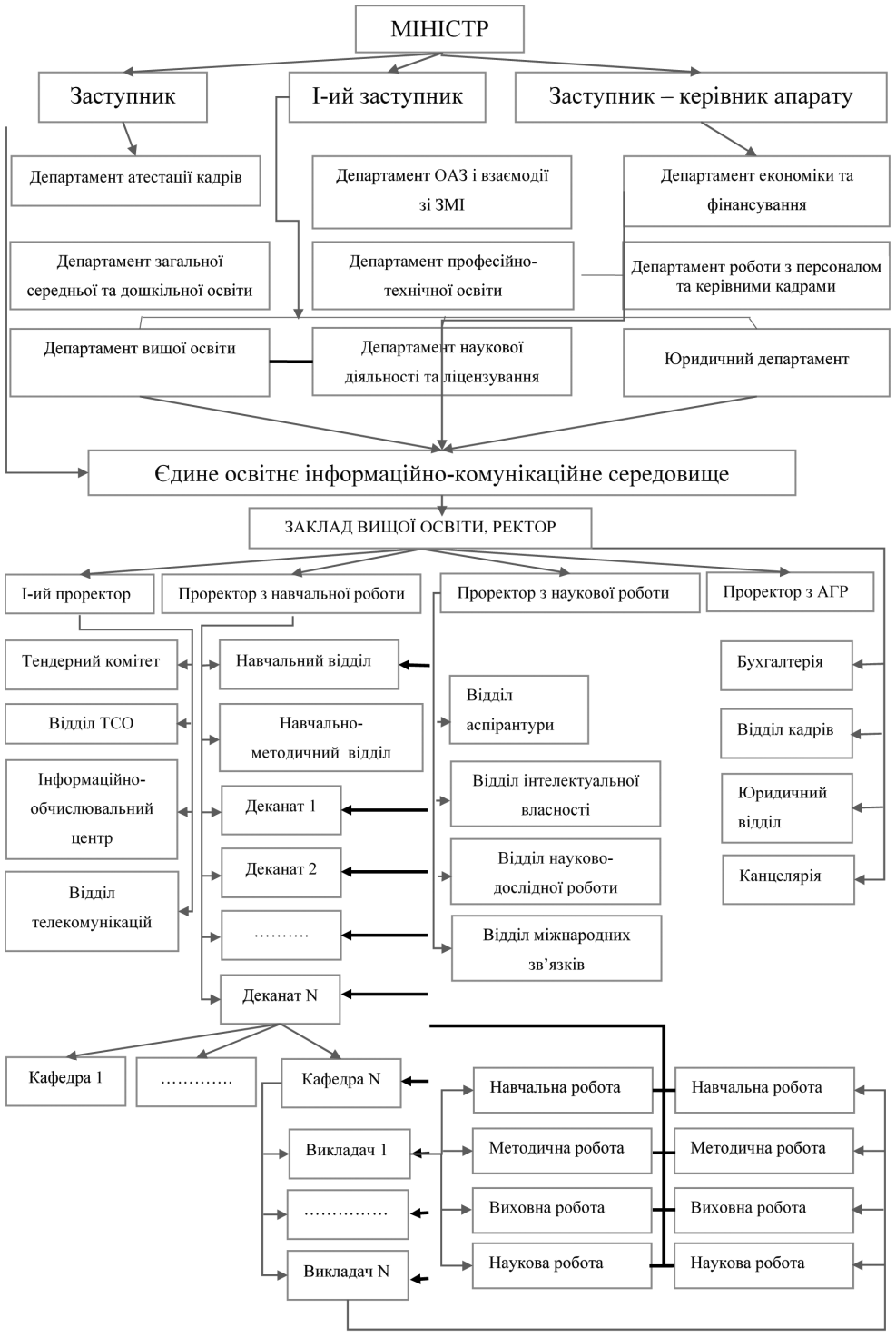

Рис. 2. Структура освітнього інформаційно-комунікаційного середовища *Джерело: власна розробка автора О. Дурман 
До основних функцій запропонованої моделі освітнього інформаційно-комунікаційного середовища належать:

- удосконалення державного управління освітньою галуззю шляхом підвищення інформованості осіб, що ухвалюють управлінські рішення, щодо діяльності підпорядкованих 3ВО;

- пришвидшення інформаційних потоків, що циркулюють всередині системи $\mathrm{MOH}$;

- забезпечення персоніфікованого і керованого доступу користувачів інформаційного середовища до інформаційних ресурсів ЗВО з різних рівнів управління, на яких це дозволено правилами доступу;

- інформаційна підтримка ділових процесів міністерства, ЗВО й організації їх управління;

- допомога користувачам у роботі в єдиному інформаційнокомунікаційному середовищі при виконанні посадових обов'язків;

- підтримка організації навчально-виховного процесу.

Середовище також може включати в себе додаткові сервіси, що реалізують інформаційну підтримку діяльності 3ВО за напрямками: адміністративне управління фінансами, організація навчального процесу, управління інформаційними ресурсами.

Організація управління закладами вищої освіти вдосконалюється засобами інформаційно-комунікаційного середовища, а саме: скорочуються витрати часу при вивченні відповідних питань і пошуку потрібної інформації, а також дозволяє оперативно, через систему зв'язків, звернутися до необхідного підрозділу.

Для створення інформаційного середовища можуть використовуватися кілька організаційних підходів. Одним 3 них є розвиток окремих додатків з їх наступною інтеграцією, використовуючи концепцію Web-служб [26].

Підхід на базі консолідації інформаційних серверів з використанням Web-служб забезпечує уніфікацію доступу до даних і додатків. Такий підхід, з одного боку, забезпечить перенос у більш сучасне інформаційне середовище функцій успадкованих додатків і дальше використання наявних даних, а 3 іншого боку - дозволить надалі впроваджувати нові інформаційні сервіси на базі єдиної тех- 
нологічної політики, що спростить супровід і розвиток корпоративного інформаційного середовища [13].

Привабливим також $є$ те, що заклади вищої освіти вже мають певні інформаційні Web системи, функціональність яких цілком адекватна стратегічним і поточним завданням діяльності вишу. Значно більше шансів бути успішним має IT-проект, у якому не потрібна кардинальна зміна всіх напрацьованих раніше й використовуваних інформаційних систем, а лише деяка їх модернізація для інтеграції в єдине середовище.

Крім того, використання Web-систем надає можливість для ефективної інтеграції даних зі структур закладів вищої освіти, розташованих у різних регіонах і містах, а також для взаємозв'язку з $\mathrm{MOH}$.

Доступ до даних у єдиному інформаційному середовищі може здійснюватися через Web-служби. Це дозволяє спростити процедури модифікації, супроводу систем i, крім того, забезпечує інтеграцію різних додатків між собою.

Забезпечуючи новий рівень простоти й гнучкості інтеграції, архітектура технологічних додатків відкриває дорогу до створення динамічного інформаційно-комунікаційного середовища галузі вищої освіти. Можна з мінімальними витратами додавати в інформаційне середовище нові сервіси, функції або дані, з огляду на нові потреби і виклики суспільства.

Висновки. Отже, в ході дослідження ми дійшли висновку, що Міністру освіти і науки або іншим уповноваженим особам важко ухвалити виважене та ефективне управлінське рішення навіть по одній процедурі (виявляється некомфортний стан управління). Цей некомфортний стан відбивається на якості не тільки управління певним 3ВО, але й на управлінні МОН України як складової державного управління. Вирішенням цієї ситуації можуть слугувати: удосконалення організаційного механізму державного управління освітньою галуззю шляхом запровадження освітнього інформаційно-комунікаційного середовища, яке б враховувало потребу вертикальної та горизонтальної взаємодії різних рівнів управління освітньою галуззю.

Спираючись на викладені раніше висновки щодо використання інформаційних технологій в освітній галузі, вважаємо, що дальші 
розробки можуть бути спрямовані на вивчення та вдосконалення механізмів державного управління освітньою галуззю через децентралізацію та дерегуляцію державного управління з метою підвищення його ефективності.

\section{Стаття надійшла до редакціi: 05.01.2019}

\section{CONCEPTUAL APPROACHES TO THE DESIGN OF THE EDUCATIONAL INFORMATION AND COMMUNICATION ENVIRONMENT}

Ivan Lopushynskyi, Head of the Department of Public Administration and Local Self-Government of Kherson National Technical University, Doctor of Public Administration, Professor, Honored Worker of Education of Ukraine

Olena Durman, Senior Lecturer of the Department of Public Administration and Local Self-Government of Kherson National Technical University, Kherson, Ukraine

The article deals with approaches to improving the organizational mechanism of management of the educational branch.

It is determined that there is an uncomfortable state of management due to a lack of information on the activities of the NGO or about the time it takes to receive it. To eliminate this uncomfortable state, it is proposed to apply the approaches, tools and tools offered by modern information and communication technologies.

To optimize management decision-making processes, it is proposed to apply approaches to decision-making theory and design and creation of appropriate information systems. This fully takes into account the new possibilities for the creation, distribution and application of multicomponent distributed and integrated databases, focused on the management and reporting process. 
In order to improve the quality and speed of management decisions in the educational sector, the formation of a unified educational information and communication environment is proposed.

The main functions of the proposed model of educational information and communication environment include:

- improving public administration in the educational sector by raising awareness of decision makers regarding the activities of subordinated NGOs;

- accelerating the flow of information circulating within the MES system;

- ensuring the personalized and managed access of users of the information environment to the information resources of the law enforcement agencies at different levels of management, in which it is allowed by the rules of access;

- informational support of the business processes of the ministry, higher education and the organization of their management;

- helping users work in a single information and communication environment while performing their official duties;

- support for the organization of the educational process.

The environment may also include additional services that implement information support for higher education in the areas of: administrative finance management, organization of the learning process, management of information resources.

This will help to improve the interaction between different levels of management of the educational branch, both vertically and horizontally. It is also proposed to extend this approach to other branch of public administration.

Keywords: public administration, educational branch, higher education system, institution of higher education, system of support of decision-making, educational information and communication environment.

\section{Received: 05.01.2019}




\section{References}

1. Bakumenko V.D. (2010). Do pytannya metodolohichnoho obgruntuvannya protsesu upravlinnya $\mathrm{v}$ sotsial'nykh systemakh [On the question of methodological substantiation of the process of management in social systems]/ amu.edu.ua Retrieved from: http://amu.edu.ua/index. php?option $=$ com_content\&task $=$ view\&id $=84$ [in Ukrainian].

2. Polovtsev O.V. (2011). Systemnyy pidkhid ta informatsiyni tekhnolohiyi pidtrymky pryynyattya rishen' $\mathrm{v}$ derzhavnomu upravlinni: [System Approach and Information Technologies for Supporting Decision-Making in Public Administration] / O.V. Polovtsev. - Donets'k: Skhidnyy vydavnychyy dim, 2010. - 206 s. [in Ukrainian].

3. Durman M.O. (2011). Symbioz kontseptsiy «novoho publichnoho menedzhmentu» ta «e uryaduvannya» yak zasib vprovadzhennya innovatsiy $\mathrm{v}$ derzhavne upravlinnya [The symbiosis of the concepts of «new public management» and «e-government» as a means of introducing innovations in public administration] «Materialy nauk.-prakt. konferentsiyi za mizhnar. Uchastyu» Materials of the scientific-practical conference with international participation. (pp. 371-373). Kyiv, 27 travnya- Kyiv: NADU [in Ukrainian].

4. Dzvinchuk D.I. (2006). Suchasna modernizatsiya system osvity i zasad upravlinnya neyu: //Osvita $\mathrm{v}$ istoryko-filosofs'komu vymiri: Tendentsiyi rozvytku ta upravlinnya : Monohrafiya / D. I. Dzvinchuk ; In-t vyshch. osvity APN Ukrayiny. - Kyyiv : Nichlava, 2006. - S. 127-179. [in Ukrainian].

5. Dombrovs'ka S. M. (2011). Mekhanizmy realizatsiyi derzhavnoyi polityky v haluzi vyshchoyi osvity [Elektronnyy resurs] / S. M. Dombrovs'ka // Aktual'ni problemy derzhavnoho upravlinnya. - 2011. - № 2. - S. 107-113. Rezhym dostupu: http://nbuv.gov.ua/UJRN/apdy_2011_2_16

6. Lopushyns'kyy I.P. (2011). Formuvannya ta realizatsiya derzhavnoyi movnoyi polityky $\mathrm{v}$ haluzi osvity Ukrayiny: dosvid, prolemy ta perspektyvy: Monohrafiya. - K. - Kherson: Oldi-plyus, 2006. - 456 s.

7. Lukina T. O. (2013). Dostupnist' osvity yak pokaznyk rezul'tatyvnosti derzhavnoho upravlinnya osvitoyu v Ukrayini [Elektronnyy resurs] / T. O. Lukina // Visnyk Natsional'noyi akademiyi derzhavnoho upravlinnya pry Prezydentovi Ukrayiny. - 2013. - № 3. - S. 114-120. - Rezhym dostupu: http:// nbuv.gov.ua/UJRN/Vnadu_2013_3_19 
8. Naumenko R.A. (2012). Derzhavne rehulyuvannya rozvytku pozashkil'noyi osvity v Ukrayini: Monohrafiya / R.A. Naumenko. - K.: Instytut obdarovanoyi dytyny, NAPN Ukrayiny, 2012. - $392 \mathrm{~s}$.

9. Parashchenko L.I. (2011). Derzhavne upravlinnya rozvytkom zahal'noyi seredn'oyi osvity v Ukrayini: metodolohiyi, stratehiyi, mekhanizmy: Monohrafiya. - K.: Mayster knyh, 2011. - 536 s.

10. Reformuvannya osvity v Ukrayini: derzhavno-upravlins'kyy aspect : navch.-nauk. vyd. (2011). / N.H. Protasova, V.I. V.I. Luhovyy, YU.O. Molchanova ta in.; za zah. red. N.H. Protasovoyi. - K.; L'viv: NADU, 2012. $456 \mathrm{~s}$.

11. Nikolayenko S. M. (2005). Vyshcha osvita - dzherelo sotsial'noekonomichnoho i kul'turnoho rozvytku suspil'stva / S. M. Nikolayenko. - K.: Znannya, 2005. - 319 s. [in Ukrainian].

12. Yakisna osvita - zaporuka samorealizatsiyi osobystosti / za zah. red. S. M. Nikolayenka, V. V. Teslenka. - K.: Ped. presa, 2007. - 176 s. [in Ukrainian].

13. Postanova KMU «Pro zatverdzhennya polozhennya pro Ministerstvo osvity i nauky Ukrayiny» vid 16 zhovtnya 2014 r. № 630. [Elektronnyy resurs]. Rezhym dostupu: https://zakon2.rada.gov.ua/laws/show/630-2014-\%D0\%BF [in Ukrainian].

14. Misiya, funktsiyi ta stratehiya Ministerstva osvity i nauky Ukrayiny. [Elektronnyy resurs]. - Rezhym dostupu: https://mon.gov.ua/ua/ministerstvo/ pro-ministerstvo/misiya-ta-funkciyi [in Ukrainian].

15. Novak V.O. (2001). Osnovy teoriyi upravlinnya: Navch. posib. - K.: NAU, 2001. - 236 s. [in Ukrainian].

16. Reforma «z'hory»: yak MON perekhodyt' na e-vryaduvannya i chomu tse stosuyet'sya kozhnoho [Elektronnyy resurs]. - Rezhym dostupu: https://saiup.org.ua/nashi-novyny/reforma-zgory-yak-mon-perehodyt-na-evryaduvannya-chomu-tse-stosuyetsya-kozhnogo/ [in Ukrainian].

17. Elektronne vryaduvannya-2017: dosyahnennya i perspektyvy. [Elektronnyy resurs]. - Rezhym dostupu: https://www.pravda.com.ua/ columns/2018/01/9/7167821/[in Ukrainian].

18. Stratehiya reformuvannya derzhavnoho upravlinnya Ukrayiny na period do 2021 roku: rozporyadzhennya Kabinetu Ministriv Ukrayiny vid 24 chervnya 2016 r. № 474-r. [Elektronnyy resurs]. - Rezhym dostupu: https:// zakon.rada.gov.ua/laws/show/474-2016-\%D1\%80 [in Ukrainian]. 
19. SIGMA [Elektronnyy resurs]. - Rezhym dostupu: http://www.center. gov.ua/pro-tsentr/proekti/sigma [in Ukrainian].

20. Polyakova L.P. (2010). Derzhavne upravlinnya informatsiyno-osvitnim seredovyshchem innovatsiynykh universytet $\cdot s$ 'kykh kompleksiv: monohrafiya / L.P. Polyakova; pid zah. red. O.S. Povazhnoho. - Donets'k: «Noulidzh» (donets'ke viddilennya ), 2010. - 351 s. [in Ukrainian].

21. Pro Natsional'nu prohramu informatyzatsiyi: Zakon Ukrayiny vid 4 lyutoho 1998 roku № 74/98-VR [Elektronnyy resurs]. - Rezhym dostupu: https://zakon.rada.gov.ua/laws/show/ 74/98-\%D0\%B2\%D1\%80 [in Ukrainian].

22. Boyko N.I. (2017). Pryntsypy formal'noho modelyuvannya informatsiynykh system na osnovi web-tekhnolohiy [Elektronnyy resurs]. Rezhym dostupu: http://ena.lp.edu.ua:8080/bitstream/ntb/20174/1/4-14-20.pdf [in Ukrainian].

23. Peleshchyshyn A.M. (1999). Pryntsypy formal'noho modelyuvannya informatsiynykh system na bazi Web-tekhnolohiy / A.M. Peleshchyshyn, YE.V. Burov // Visnyk Derzh. un-tu «L’vivs’ka politekhnika». - № 383. - S. 178-201 [in Ukrainian].

24. Burov YE.V. (1998). Analiz ta optymizatsiya informatsiynykh potokiv u suchasnykh internet ta intranet systemakh / YE.V. Burov, A.M. Peleshchyshyn // Visnyk Derzh. un-tu «L'vivs'ka politekhnika». - 1998. - № 330.- S. 27-34. [in Ukrainian].

25. Burov YE.V. (1998). Optymizatsiya rozmishchennya danykh u Websystemakh / YE.V. Burov, A.M. Peleshchyshyn // Visnyk Derzh. un-tu «L'vivs'ka politekhnika». — № 330. - S. 17-27 [in Ukrainian].

26. Sushchuk O.A. Mizhnarodni informatsiyni systemy [Tekst] / O.A. Sushchuk. - K.: UZMN, 2002. - 148 s. [in Ukrainian]. 


\section{Відомості про авторів / Information about the Authors}

Лопушинський Іван Петрович: Херсонський національний технічний університет вул. Бериславське шосе 24, Херсон, 73008, Україна.

Ivan Lopushynskyi: Kherson National Technical University: Beryslavskoe highway 24, Kherson, 73008, Ukraine.

\section{ORCID.ORG/0000-0002-3930-746X}

\section{E-mail: doctordumetaua@meta.ua}

Дурман Олена Леонідівна: Херсонський національний технічний університет вул. Бериславське шосе 24, Херсон, 73008, Україна.

Olena Durman: Kherson National Technical University: Beryslavskoe highway 24, Kherson, 73008, Ukraine.

\section{E-mail: doctordumetaua@meta.ua}

